\title{
Peranan Public Relations Dalam Mempertahankan Eksistensi Ramayana
}

\author{
Citra Anggraini, Yugih Setyanto \\ citra.915160003@stu.untar.ac.id,yugihs@fikom.untar.ac.id \\ Fakultas Ilmu Komunikasi Universitas Tarumanagara
}

\begin{abstract}
Public Relations have a role to maintaining the company's existence. Existence is very necessary to be announced at the company. Lots of competing retail businesses provide all the needs of visitors and offer quality products at affordable prices. Thus the existence of a company as a characteristic is determined by competitors. This research uses the theory of existence and the role of $P R$. The research study used in this research is descriptive qualitative research with case study research methods and data collection techniques carried out by interviews, non-participant observation, literature study and documentation. The results of this study indicate that PR Ramayana carries out special activities and programs such as Corporate Social Responsibility (CSR) activities that maintain the name, image, and existence of the community. CSR activities are carried out not only in the form of financial assistance, but also in the form of public education. In addition, to keep pace with technological developments, Ramayana also pays attention to activities on social media.
\end{abstract}

Keywords: company existence, corporate social response (CSR), role of PR.

\section{Abstrak}

Public Relations berperan dalam menjaga dan mempertahankan eksistensi perusahaannya. Eksistensi sangat dibutuhkan untuk menunjukkan keberadaan perusahaan di masyarakat. Banyak sekali bisnis retail yang bersaing menyediakan semua kebutuhan pengunjung secara lengkap dan menawarkan produk yang berkualitas dengan harga terjangkau. Dengan demikian dibutuhkan eksistensi perusahaan sebagai ciri khas yang membedakan dengan kompetitor Penelitian ini menggunakan teori eksistensi dan peranan PR. Pendekatan penelitian yang digunakan dalam penelitian ini adalah pendekatan kualitatif deskriptif dengan metode penelitian studi kasus dan teknik pengumpulan data dilakukan dengan wawancara, observasi non-participant, studi pustaka dan dokumentasi. Hasil penelitian menunjukan bahwa PR Ramayana telah melakukan kegiatan dan program khusus seperti kegiatan Corporate Social Responsibility (CSR) yang bertujuan untuk mempertahankan nama, citra, dan eksistensi kepada masyarakat. Kegiatan CSR dilakukan tidak semata-mata dalam bentuk pemberian sumbangan dana, tetapi juga dalam bentuk edukasi kepada masyarakat. Selain itu, untuk mengimbangi perkembangan teknologi, Ramayana juga memperhatikan aktivitas di media sosial.

Kata Kunci: corporate social responsibility (CSR), eksistensi perusahaan, peran PR

\section{Pendahuluan}

Perusahaan membutuhkan peranan Public Relations untuk membantu kegiatan manajemen perusahaan. Hal ini terbukti dari banyaknya bagian atau divisi Public Relations yang dibentuk dalam setiap perusahaan. Dalam suatu perusahaan, salah satu tugas pokok yang dilakukan Public Relations adalah mempertahankan eksistensi 
perusahaan sehingga dibutuhkan sebuah strategi agar perusahaan dapat mencapai tujuan tersebut.

Menurut Cutlip dan Center (2009) Public Relations merupakan bagian dari fungsi manajemen yang bertugas menilai sikap publik, mengidentifikasi kebijaksanaan dan tata cara seseorang atau organisasi demi kepentingan publik, serta melakukan perencanaan suatu kegiatan dan program untuk memperoleh dan memenuhi dukungan dan eksistensi publik. Sedangkan, menurut Frank Jefkins (2003) Public Relations merupakan suatu bentuk komunikasi yang terencana, baik komunikasi yang dilakukan ke dalam maupun ke pihak luar, antara suatu organisasi dengan semua khalayaknya untuk mencapai tujuan-tujuan spesifik yang berlandaskan pada saling pengertian.

Kegiatan Public Relations dibutuhkan agar dapat membangun image dan identitas perusahaan, terutama dalam bidang komunikasi yang berlangsung dalam suatu perusahaan agar mampu menjaga dan mempertahankan eksistensi di tengah persaingan. Hampir setiap perusahaan saat ini berkompetisi untuk menunjukan eksistensinya, dengan menampilkan berbagai kelebihan-kelebihan untuk meningkatkan awareness dan kepercayaan kepada masyarakat.

Eksistensi berasal dari bahasa Inggris "exist" yang berarti ada, terdapat hidup atau dirasakan keberadaanya. Menurut Kamus Besar Bahasa Indonesia (KBBI), eksistensi adalah keberadaan, kehadiran yang mengandung unsur bertahan. Public Relations bertujuan untuk membangun pengertian publik terhadap organisasi agar dapat terbangun hubungan yang baik dan saling menguntungkan antara organisasi dan publiknya dan terpelihara pulalah citra organisasi tersebut (Iriantara, 2004).

Eksistensi suatu lembaga tidak lepas dari peran Public Relations dalam menjalankan fungsinya sebagai komunikator yang aktif terhadap setiap isu maupun perubahan yang ada. Public Relations bertujuan untuk membangun pemahaman publik terhadap organisasi sehingga dapat terbangun hubungan yang baik dan saling menguntungkan antara organisasi dan publiknya dan terpelihara pulalah citra organisasi tersebut (Iriantara, 2004).

Salah satu bidang usaha yang membutuhkan peranan Public Relations untuk mendongkrak image adalah perusahaan ritel yang bergerak dalam bidang Department Store. Menurut proyeksi nilai pasar pakaian dan aksesoris di Asia Pasifik, jumlah pasar ritel modern di Indonesia adalah sebesar 11.866 (www.idx.co.id). Berkembangnya perusahaan ritel yang bergerak dalam bidang Department Store telah menuntut perusahaan untuk memperhatikan pentingnya peran Public Relations dalam perusahaan.

Pengusaha ritel dalam bidang Department Store harus dapat melihat pengunjung sebagai faktor yang menjadi prioritas utama karena eksistensi suatu perusahaan ritel sangat tergantung pada seberapa banyak masyarakat yang mengenal dan jumlah pengunjung. Peranan seorang Public Relations officer tentunya dihadapkan pada tantangan untuk menarik para pengunjung. Hal ini menuntut kreativitas pengembangan usaha yang kompetitif sesuai dengan keinginan dan kebutuhan pengunjung dan publikasi yang dapat meningkatkan jumlah pengunjung.

Sebagai perusahaan ritel di bidang Department Store yang sudah cukup lama berdiri dan dikenal oleh masyarakat umum, Ramayana dituntut untuk mempertahankan atau meningkatkan jumlah pengunjung jika ingin tetap bertahan di tengah persaingan yang ketat ini. Keunikan lain yang dimiliki Ramayana adalah memiliki banyak cabang yaitu mencapai 116 gerai yang tersebar di seluruh Indonesia. Ramayana merupakan Department Store yang memiliki cabang terbanyak di Indonesia, dan hampir tidak pernah terdengar kabar bahwa gerai Ramayana tutup. Jika 
diamati, gerai Ramayana selalu berdiri sendiri atau terpisah dari pusat perbelanjaan lain. Hal ini merupakan salah satu strategi perusahaan untuk mengurangi tingkat persaingan.

Salah satu cara agar perusahaan dapat terus eksis dan dikenal masyarakat adalah dengan meningkatkan peranan seorang Public Relations dalam mengelola kegiatan-kegiatan dan program yang akan memberikan dampak positif jika diterapkan di dalam perusahaan.

Melalui penjelasan di atas, maka peranan Public Relations merupakan salah satu hal yang menarik untuk dikaji karena berhubungan dengan tingkat eksistensi perusahaan Ramayana di kalangan masyarakat. Selama ini penelitian yang dilakukan hanya sebatas mengenai pembentukan citra positif perusahaan. Maka, penelitian ini lebih difokuskan mengenai hal-hal yang berkaitan dengan peranan Public Relations pada perusahaan secara berkelanjutan akan mempengaruhi eksistensi perusahaan.

\section{Landasan Teori}

Definisi Public Relations menurut Cultip, Center dan Broom dalam bukunya Effective Public Relations Edisi Kesembilan adalah fungsi manajemen yang membangun dan mempertahankan hubungan yang baik dan bermanfaat antara organisasi dengan publik yang mempengaruhi kesuksesan atau kegagalan organisasi tersebut (Cutlip, 2007).

Menurut Dozier dan Broom, peranan PR antara lain (Dozier \& Broom, 1995):

1. Penasehat Ahli (Expert Prescriber)

Seorang praktisi Public Relations yang berpengalaman dan memiliki kemampuan tinggi dapat membantu mencarikan solusi dalam penyelesaian masalah hubungan dengan publiknya.

2. Fasilitator Komunikasi (Communication Fasilitator)

Dalam hal ini, praktisi Public Relations bertindak sebagai komunikator atau mediator untuk membantu pihak manajemen dalam hal mendengar apa yang diinginkan dan diharapkan oleh publiknya.

3. Fasilitator Proses Pemecahan Masalah (Problem Solving Process Fasilitator)

Peranan praktisi Public Relations dalam pemecahan masalah persoalan. Public Relations merupakan bagian dari tim manajemen. Hal ini dimaksudkan untuk membantu pimpinan organisasi baik sebagai penasehat (adviser) hingga pemimpin organisasi mampu mengambil tindakan dan mengeksekusi keputusan dalam mengatasi persoalan atau krisis yang tengah dihadapi, secara rasional dan profesional.

4. Teknisi Komunikasi (Communication Technician)

Peranan communications technician ini menjadikan praktisi Public Relations sebagai journalist in recident yang hanya menyediakan layanan teknis komunikasi atau dikenal dengan of communication in organization.

Menurut Ruslan (2005) dikatakan peranan utama seorang PR adalah sebagai komunikator atau penghubung antara perusahaan dengan publiknya.

(1) membina relationship, yaitu berupaya membina hubungan yang positif dan saling menguntungkan dengan publiknya.

(2) peranan backup management, yakni sebagai pendukung dalam fungsi manajemen perusahaan.

(3) membentuk corporate image, artinya peranan PR berupaya menciptakan citra bagi organisasi atau lembaganya. 


\section{Metode Penelitian}

Jenis Penelitian pada skripsi ini adalah penelitian kualitatif. Menurut Moleong, penelitian kualitatif adalah penelitian yang bermaksud untuk memahami fenomena tentang apa yang dialami oleh subjek penelitian misalnya perilaku, persepsi, motivasi, tindakan, dan lain-lain secara holistic, dan dengan cara deskripsi dalam bentuk katakata dan bahasa, pada suatu konteks khusus yang alamiah dan dengan memanfaatkan berbagai metode alamiah (Moleong, 2005).

Penelitian kualitatif adalah penelitian yang digunakan untuk meneliti pada kondisi objek alamiah, dimana peneliti merupakan instrumen kunci (Sugiyono, 2005). Informasi diperoleh dari pernyataan hasil wawancara dengan seorang Public Relations Ramayana.Dalam melaksanakan penelitian ini, data dan fakta diperoleh menggunakan teknik wawancara.

Penelitian ini menggunakan pendekatan kualitatif karena penelitian ini menganalisis dan mendeskripsikan peranan Public Relations Ramayana dalam mempertahankan eksistensi di tengah persaingan, informasi diperoleh dari pernyataan hasil wawancara dengan seorang Public Relations Ramayana. Wawancara yang dilakukan dalam penelitian ini yaitu dengan mewawancarai Public Relations Ramayana. Pengumpulan data primer dilakukan melalui wawancara mendalam (Indepth Interview), observasi, dan dokumentasi.

Selain melalui wawancara, data primer diperoleh melalui observasi dan dokumentasi. Observasi yaitu melakukan pengamatan terhadap kejadian-kejadian dan perilaku yang terjadi terkait penelitian. Observasi berkaitan dengan situasi tempat pengamat melakukan penelitian. Dokumentasi dilakukan dengan mengumpulkan informasi tertulis dengan membaca literatur, tulisan, maupun dokumen yang berkaitan dengan penelitian.

Data sekunder dikumpulkan sebagai data pendukung penelitian. Menurut Sugiyono, data sekunder adalah sumber data yang tidak langsung memberikan data kepada pengumpul data, misalnya lewat orang lain atau lewat dokumen (Sugiyono, 2015). Data sekunder pada penelitian ini diperoleh melalui studi pustaka dan literaturliteratur yang berkaitan dengan penelitian. Peneliti mencari referensi mengenai informasi seputar Ramayana berkaitan dengan eksistensi dan citra perusahaan melalui website dan situs pemberitaan online. Dalam melaksanakan penelitian ini, untuk memperoleh data dan fakta yang diperlukan berkaitan dengan tujuan penelitian. Penulis menggunakan metode penelitian studi kasus.

\section{Hasil Temuan dan Diskusi}

PT. Ramayana terbilang merupakan salah satu pusat perbelanjaan yang telah berdiri sejak lama. Eksistensi Ramayana cukup baik hingga masih dikenal keberadaannya oleh masyarakat Indonesia, walaupun sekarang banyak kompetitor bisnis sejenis yang berkembang di pasaran. Menurut Setyadi selaku PR Ramayana mengatakan untuk memperoleh eksistensi, diperlukan pencitraan di masyarakat.

Permasalahan yang dihadapi yaitu apa yang menjadi ciri khas Ramayana agar berbeda dari toko konvensional lain. Dulu, Ramayana dikenal sebagai toko yang murah, toko diskon dan lain sebagainya. Ramayana juga terus memperbarui sistem komunikasi pemasaran yang dilakukan, sekarang memanfaatkan media sosial agar tetap eksis di kalangan anak milenial. 
Dalam buku Komunikasi Manusia: Teori dan Praktik Dalam Penyampaian Gagasan oleh Dr. Eko Harry Susanto, dengan hadirnya media sosial seperti sekarang akan memberikan kemudahan bagi pemakainya dalam proses penyampaian pesan melalui perantara jaringan sosial, media visual dan lain-lain (Susanto, 2018). Karena masyarakat sudah berubah, teknologi sudah semakin maju. Maka, Ramayana juga harus berubah mengikuti siklus tersebut.

Di perusahaan ini, peran Public Relations dan sekretaris perusahaan menjadi satu-kesatuan. Alasannya adalah sekretaris dianggap sebagai pihak internal yang mengetahui segala kondisi perusahaan. Sedangkan, Public Relations sebagai bagian yang mengamati perilaku konsumen dan mengevaluasi program PR yang tepat untuk dilakukan. Maka, perusahaan Ramayana menempatkan dua bagian ini menjadi satu divisi karena dianggap memiliki saling ketergantungan.

Sekretaris Perusahaan bertugas bertanggung jawab untuk memastikan bahwa jalannya perusahaan mematuhi seluruh prosedur yang ditetapkan di Undang-Undang. Selain itu, sekretaris perusahaan juga bertanggung jawab atas semua laporan-laporan perusahaan, mulai dari laporan keuangan, laporan hasil penjualan, proposal mengenai kegiatan perusahaan, anggaran program PR, dan surat-surat penting terkait perusahaan.

Public Relations bertugas memelihara hubungan dengan berbagai otoritas pasar modal dan dengan pemegang saham, perwakilan media massa, masyarakat sekitar dan publik secara luas. Di samping itu, Public Relations harus mengamati perilaku publik sebagai tolak ukur keberhasilan program PR yang dijalankan, dan selanjutnya merencanakan program-program lain yang bertujuan untuk menaikkan citra dan eksistensi perusahaan. Maka, divisi ini dianggap sebagai perantara antara perusahaan dan publik.

Public Relations berperan dalam membangun dan menjaga citra perusahaan. Pentingnya penjagaan citra organisasi menjadi tanggung jawab PR, pencitraan yang baik ini dapat memberikan dampak yang baik juga untuk keberlanjutan perusahaan, hal ini disampaikan oleh William P. Nickons (2005). Untuk membangun citra perusahaan, strategi yang dilakukan seorang PR adalah melakukan CSR (Corporate Social Responsibility).

CSR merupakan komitmen perusahaan atau dunia bisnis untuk berkontribusi dalam pembangunan ekonomi yang berkelanjutan dengan menitikberatkan pada keseimbangan antara perhatian terhadap aspek ekonomi, sosial, dan lingkungan (Priyanto, 2008:57). Menurut Setyadi pada saat PR mendekatkan diri pada masyarakat dengan mengadakan kegiatan CSR, kendala yang membatasi hal tersebut adalah seberapa banyak dana yang disediakan perusahaan untuk mengadakan kegiatan CSR tersebut. CSR diadakan harus sesuai dengan anggaran yang diberikan perusahaan.

Menurut Setyadi Surya sebagai PR dan corporate secretary PT. Ramayana, kegiatan pendekatan yang dilakukan perusahaan kepada masyarakat melalui kegiatan CSR harus dapat menyentuh kehidupan sosial masyarakat. Kegiatan CSR tidak hanya sekedar memberikan sumbangan, tetapi dapat dilakukan kegiatan donor darah atau pengobatan gratis. Seperti pada 2018 lalu, Ramayana mengadakan pemeriksaan dan pengobatan gratis di Cikarang dengan menghadirkan 60 dokter profesional dan beberapa bantuan tim media.

Selain itu, pendekatan kepada masyarakat juga bisa dalam bentuk edukasi, seperti memberikan penyuluhan mengenai dunia bisnis dan sebagainya. Selain itu, menjalin hubungan dengan masyarakat yang membutuhkan, Ramayana juga 
menunjukkan kepedulian mereka dengan masyarakat sekitar Jl. KH Wahid Hasyim seperti PR Ramayana ikut menghadiri jika diundang oleh camat untuk menghadiri suatu acara atau rapat. Dan juga hubungan dengan pemerintah penting dijaga untuk mempermudah perihal mengenai prosedur pemerintahan.

Adapun peran PR dalam menjaga eksistensi yang disampaikan Ruslan (2005) yaitu sebagai pembina relationship, peranan backup management, dan membentuk corporate image. Membentuk corporate image yaitu PR berupaya menciptakan citra positif bagi perusahaan. Ramayana yang ber diri dari dahulu hingga sekarang pasti memiliki konsep yang baru dan butuh pencitraan yang kuat untuk mempertahankan corporate image di masyarakat.

PR melakukan pembinaan relationship dengan semua pihak, baik pihak eksternal maupun pihak internal. PR tidak hanya membina hubungan baik dengan para pengunjung, melainkan seluruh pihak seperti pemerintah, investor, karyawan perusahaan, dan sebagainya. Peranan backup management yaitu PR bekerja sama dengan divisi lain dalam mewujudkan visi dan misi perusahaan, karena PR merupakan divisi yang tidak dapat berdiri sendiri. PR membutuhkan kerja sama dengan divisi bagian lain agar program PR dapat terlaksanakan dengan baik.

Menurut Dozier dan Broom (1995), peranan PR antara lain sebagai penasehat ahli, fasilitator komunikasi, fasilitator pemecahan masalah, dan teknisi komunikasi. Berkaitan dengan pendapat tersebut, menurut Setyadi peran PR adalah sebagai fasilitator yang menghubungkan antara kepentingan perusahaan dan kebutuhan masyarakat, PR mendengarkan dan menyampaikan apa yang diharapkan dan diinginkan oleh publiknya kepada bagian management perusahaan. Selain itu, PR berperan sebagai fasilitator dalam membantu proses pemecahan masalah, seperti PR memberikan kebijakan dan keputusan khusus kepada konsumen yang mengajukan keluhan. Selain itu, PR juga membantu bagian management terhadap permasalahan yang dihadapi perusahaan.

Banyak sekali perusahaan e-commerce saat ini bermunculan. Menurut Setyadi selaku PR Ramayana, brand Ramayana bergabung di beberapa $e$-commerce bukan berarti mereka takut tertinggal oleh perkembangan zaman atau tidak laku. Karena tujuan Ramayana bergabung dalam Lazada, Tokopedia dan Shopee adalah atas motif bisnis. Setyadi melihat hal ini bukan sebagai ancaman, karena toko online dan toko konvensional memiliki kelebihan dan kelemahan masing-masing. Maka, Ramayana memilih untuk berkolaborasi dengan perusahaan-perusahaan e-commerce hanya semata untuk test market dan lebih mengutamakan penjualan.

Selain itu, hal ini juga dapat berdampak pada tingkat eksistensi Ramayana, karena kaum milenial sekarang lebih sering mengakses dan memanfaatkan transaksi melalui situs belanja online. Maka, Ramayana memilih berkolaborasi dalam bidang e-commerce untuk mengembangkan bisnis ritelnya.

Salah satu program PR yang dilaksanakan PR untuk menjaga eksistensi dan kesetiaan pelanggan mereka yaitu melalui adanya kartu member Ramayana. Konsumen yang memiliki member Ramayana akan mendapatkan beberapa keuntungan, seperti menukarkan poin dengan merchandise yang tersedia, mendapatkan potongan harga atau promo menarik di merchant yang bekerja sama dengan Ramayana. Hal tersebut merupakan salah satu program PR yang dilaksanakan oleh Ramayana, karena bertujuan untuk menjaga kesetiaan pengunjung terhadap Ramayana. 
Menyesuaikan perkembangan zaman, Ramayana menyediakan aplikasi khusus Ramayana Member Card yang dapat diakses melalui gadget. Melalui aplikasi ini, pemilik member card dapat mengetahui jumlah poin yang terkumpul saat ini, mengetahui merchandise yang dapat ditukar dengan poin, member juga mendapatkan promo, produk flash sale, dan penawaran khusus melalui aplikasi. Selain itu, melalui aplikasi ini member dapat membeli produk yang dipesan secara online dan pengambilan pesanan di outlet Ramayana terdekat. Ramayana juga bekerja sama dengan DANA sebagai alternatif metode pembayaran non tunai, pembayaran dengan DANA akan mendapatkan cashback.

\section{Kesimpulan}

Dari hasil penelitian mengenai "Peranan Public Relations Dalam Mempertahankan Eksistensi Ramayana". Peneliti menarik kesimpulan bahwa Ramayana merupakan salah satu Department Store yang berdiri selama empat puluh satu tahun, untuk mempertahankan eksistensi di kalangan masyarakat dibutuhkan peranan PR yaitu melakukan program kegiatan Corporate Social Responsibility (CSR) sebagai bentuk pendekatan dengan masyarakat. Kegiatan CSR yang dilakukan tidak hanya melalui sumbangan, tetapi juga melalui penyuluhan tentang bisnis, donor darah, dan sebagainya.

Faktor eksistensi Ramayana hingga sekarang adalah menjaga relationship dengan pihak eksternal, seperti publik secara luas, masyarakat sekitar, pemerintah, media, Bursa Efek, karyawan, dan mitra kerja lain. Dan juga, Ramayana berkolaborasi dengan perusahaan e-commerce sebagai mitra bisnis. PR Ramayana memanfaatkan media sosial sebagai sarana mempublikasikan informasi seputar perusahaannya. Seperti menginformasikan seputar event meet and great dengan artis, acara pameran (exhibition), informasi seputar produk keluaran terbaru, dan masih banyak kegiatan lain yang dipublikasikan melalui sosial media milik Ramayana. Hal ini bertujuan agar keberadaan Ramayana masih diakui publik.

Tak kalah penting, yaitu PR Ramayana juga menjaga pelanggan setia dengan memberikan kartu member Ramayana. Melalui kartu member ini, pelanggan akan mendapatkan beberapa benefit seperti potongan harga, poin belanja, dan hadiah menarik. Saat ini juga tersedia aplikasi khusus member Ramayana, pelanggan dapat memesan produk secara online dan mengambil pesanan di store terdekat.

\section{Ucapan Terima Kasih}

Penulis mengucapkan terima kasih kepada seluruh dosen Fakultas Ilmu Komunikasi Universitas Tarumanagara, kepada orangtua, saudara, narasumber, dan teman-teman yang sudah mendukung dan membantu penulis dalam menyelesaikan penelitian hingga pembuatan jurnal ini.

\section{Daftar Pustaka}

Cutlip, Scott M. et. al. (2007). Effective Public Realtions, Edisi IX, cetakan ke-2. Jakarta : Kencana.

Creswell, J. W. (2010). Research design: pendekatan kualitatif, kuantitatif, dan mixed. Yogyakarta: PT Pustaka Pelajar.

Iriantara, Yosal. (2004). Manajemen Strategis Public Relations. Jakarta: Ghalia. 
Jefkins, Frank. (2003). Public Relations Edisi kelima, Jakarta: PT Gelora Aksara Pratama.

Moleong, Lexy J. (2005). Metodologi Penelitian Kualitatif. Bandung : Remaja Rosdakarya.

Ruslan, Rusady. (2005). Manajemen Public Relations dan Media Komunikasi. Jakarta: PT. Raja Grafindo Persada.

Sugiyono. (2005). Memahami Penelitian Kualitatif. Bandung: CV. Alfabeta.

Sugiyono. (2015). Metode Penelitian Kombinasi (Mix Methods). Bandung: Alfabeta

Susanto, Eko Harry. (2018). Komunikasi Manusia: Teori dan Praktik Dalam Penyampaian Gagasan. Jakarta: Penerbit Mitra Wacana Media 